\title{
QUALIFICATION OF TLC-EQUIPMENT USED IN ANALYSIS OF THE COMBINED HERBAL MEDICINES
}

\author{
V.K.Iakovenko, K.O.Khokhlova \\ National University of Pharmacy
}

Key words: quality control system; analysis; TLC-equipment; Klimased

\begin{abstract}
On the example of Klimased drug with the purpose of choosing the analytical equipment for quality control of combined drugs of the plant origin the study on major functional and performance characteristics (design qualification) of the equipment used according to pharmacopoeial requirements(SPhU and USP) and the target analytical tasks has been conducted. It allows to select equipment for an enterprise. A comparative analysis of functional and technical specifications of the devices to perform analysis of the combined drugs from the medicinal plant raw material by the method of thin-layer chromatography has been conducted. It has been experimentally proven that the configuration of the chromatographic chamber does not affect the result of the analysis, chambers manufactured by Sorbfil are more affordable by economic indicators. When analysing the medicinal plant raw material and drugs from it the TLC and HPTLC plates on all substrates with an UV indicator can be used, it is advisable to make the final choice by economic components or their availability. Characteristics of the devices for applying solutions of chromatograms have revealed that when choosing microsyringes the best indicator is its volume. When comparing devices for detecting or quenching fluorescence manufactured by Sorbfil (Russia) and Spectroline (USA) it has been proven that each of the devices studied can be used to identify chromatographic zones. The manufacturer Spectroline has the quality certificate ISO 9001:2008 and is more affordable, therefore, it is superior to irradiator UVS-254/365 manufactured by Sorbfil. Among the devices for spraying chromatograms the sprayers of GGB (USA) have a comfortable design and a suitable volume, but by cost they are much more expensive than sprayers of Sorbfil (Russia). It is advisable to make the final choice based on the economic component.
\end{abstract}

A key element in organization of production and quality management is the quality control system, and one of its main objectives is to obtain reliable results during the analysis. Such results are only possible when using laboratory equipment with the required technical characteristics and correct functioning.

Equipment qualification is a necessary preliminary step for validation/verification of analytical methods $[1,4,8]$.

The aim of our paper was to qualify the laboratory equipment used in the analysis of a multicomponent herbal drug Klimased by thin-layer chromatography (TLC).

\section{Materials and Methods}

When evaluating the quality of Klimased drug according to its Drug Master File (DMF) such physical and physicochemical methods of analysis as TLC, HPLC, GC, etc., were used.

On the example of Klimased drug with the purpose of choosing the analytical equipment for its quality control the study of major functional and performance characteristics (design qualification) of the equipment used according to pharmacopoeial requirements (SPhU and USP) and the target analytical tasks were conducted. It allows to select equipment for an enterprise $[2,3,6,7,9]$.

In the process of our study the propositions of manufacturers that supply analytical equipment used to identify the active substances of the drug under research (TLC) to the pharmaceutical market of Ukraine were analyzed.

Results and Discussion

The results of analysis of the requirements of the SPhU and USP to the equipment used in the TLC me- thod in the qualitative analysis of Klimased are given in Tab. 1.

A comparative analysis of functional and technical specifications of the devices to perform analysis by the method of thin-layer chromatography is given in Tab. 2 .

As Tab. 2 shows, a comparative analysis of functional characteristics of the chromatographic chambers of different manufacturers (Sorbfil, Russia and GGB, USA) has found that the size of the plate affects the choice of chambers for conducting the experiment. The Latch-LID Chromatotanks model $(27 \times 7 \times 26 \mathrm{~cm})$ manufactured by GGB (USA) is optimal when using the TLC plates with the size of $20 \times 10$ (for simultaneous analysis of many samples). It has been experimentally proven that the configuration of the chromatographic chamber does not affect the result of the analysis [5]. Chambers manufactured by Sorbfil are more affordable by economic indicators.

Comparative characteristics of analytical and highperformance plates for TLC of such manufacturers as Sorbfil (Russia), Macherey-Nagel (Germany), Merck (Germany) have found that as a sorbent all plates contain silica gel, which is selective in separation of compounds containing various functional groups of the medicinal plant raw material (the medicinal plant raw material and drugs with the medicinal plant raw material) $[5,6,8]$. The plates under research contain aluminium, polyethylene terephthalate, glass as a substrate, each of them has advantages (inert glass material, aluminium and polyethylene terephthalate are easy to use) $[5,6]$. When ana- 
Qualification of equipment for TLC analysis of Klimased drug (requirements of the SPhU and USP)

\begin{tabular}{|c|c|c|}
\hline Equipment & Requirements of the SPhU & Requirements of the USP \\
\hline \multirow{3}{*}{ TLC or HPTLC plates } & \multicolumn{2}{|c|}{$\begin{array}{l}\text { The stationary phase consisting of a suitable material applied in the form of a standardized } \\
\text { thin layer and fixed on the base (plate) made of glass, metal or plastic }\end{array}$} \\
\hline & $\begin{array}{l}\text { To use plates made in industrial conditions is permit- } \\
\text { ted if they comply with the requirements of section } \\
\text { 4.1.1. "Reagents», as well as "System suitability test" } \\
\text { described in a separate article. It is recommended to } \\
\text { determine convergence of } R_{f} \text {. values }\end{array}$ & $\begin{array}{l}\text { To use plates made in industrial condi- } \\
\text { tions is permitted }\end{array}$ \\
\hline & $\begin{array}{l}\text { The substrate is made of glass, metal or plastic, coat- } \\
\text { ed with a layer of silica gel with a suitable thickness } \\
\text { and particle size for HPTLC plates }-2-10 \mu \mathrm{m} \text { and for } \\
\text { common TLC plates }-5-40 \mu \mathrm{m} \text {. If necessary, the par- } \\
\text { ticle size is indicated after the name of the sorbent in } \\
\text { the tests where it is used. The sorbent may contain an } \\
\text { organic binding substance }\end{array}$ & $\begin{array}{l}\text { The average particle size for HPTLC } \\
\text { plates }-5 \mu \mathrm{m} \text {, for TLC plates } 10-15 \mu \mathrm{m}\end{array}$ \\
\hline $\begin{array}{l}\text { Micropipettes, } \\
\text { microsyringes, } \\
\text { calibrated capillaries }\end{array}$ & Devices suitable for applying solutions & $\begin{array}{l}\text { Manual, semi-automatic or automatic de- } \\
\text { vices for applying samples. A template } \\
\text { for drawing zones manually at specific } \\
\text { intervals, measuring the distance and } \\
\text { assisting in labelling can be addition- } \\
\text { ally used }\end{array}$ \\
\hline $\begin{array}{l}\text { Chromatographic } \\
\text { chamber }\end{array}$ & \multicolumn{2}{|c|}{$\begin{array}{l}\text { The container with a tight fitting lid and a flat bottom or a bottom with two troughs made of } \\
\text { an inert transparent material corresponding to the size of the plates used }\end{array}$} \\
\hline $\begin{array}{l}\text { Developing devices or } \\
\text { reagents }\end{array}$ & \multicolumn{2}{|c|}{$\begin{array}{l}\text { Suitable devices used to transfer reagents on the plate by spraying, vapour treatment or im- } \\
\text { mersion that provide, if necessary, heating to detect the compounds separated }\end{array}$} \\
\hline $\begin{array}{l}\text { Devices for detecting or } \\
\text { quenching fluorescence }\end{array}$ & Requirements are not given & $\begin{array}{l}\text { The UV light source for examining in the } \\
\text { short-wave }(254 \mathrm{~nm}) \text { and long-wave } \\
(365 \mathrm{~nm}) \text { light }\end{array}$ \\
\hline Documentation & $\begin{array}{l}\text { For example, photographs or computer files can be } \\
\text { used for documenting the chromatograms detected }\end{array}$ & $\begin{array}{l}\text { A suitable device to register the chro- } \\
\text { matograms detected }\end{array}$ \\
\hline
\end{tabular}

Table 2

A comparative analysis of functional and technical specifications of the devices for TLC analysis and their cost

\begin{tabular}{|c|c|c|c|}
\hline Equipment & Name & Description & Cost \\
\hline 1 & 2 & 3 & 4 \\
\hline \multicolumn{4}{|c|}{ Chromatographic chamber } \\
\hline \multirow{3}{*}{$\begin{array}{l}\text { Sorbfil, } \\
\text { Russia }\end{array}$} & $\begin{array}{l}\text { Chromatographic chamber with a } \\
\text { dividing ledge for plates of } 10 \times 10 \mathrm{~cm} \text {. } \\
\text { The size }-(150 \times 120 \times 80 \mathrm{~mm})\end{array}$ & \multirow{3}{*}{$\begin{array}{l}\text { Chambers are made of chemically resistant glass. } \\
\text { They have a dividing ledge at the bottom for fixing } \\
\text { plates and saving the eluent. Chambers are supplied } \\
\text { with a ground lid }\end{array}$} & 2000 RUB \\
\hline & $\begin{array}{l}\text { Chromatographic chamber for plates } \\
\text { of } 15 \times 15 \mathrm{~cm} \text {. } \\
\text { The size }-(150 \times 120 \times 80 \mathrm{~mm})\end{array}$ & & 2850 RUB \\
\hline & $\begin{array}{l}\text { Chromatographic chamber for plates } \\
\text { of } 15 \times 15 \mathrm{~cm} \text { (glued with silicone). } \\
\text { The size }-(190 \times 195 \times 65 \mathrm{~mm}) \\
\end{array}$ & & 1600 RUB \\
\hline GGB, USA & $\begin{array}{l}\text { Chromatographic chamber with a flat } \\
\text { bottom (Latch-LID Chromatotanks). } \\
\text { The size }-(27 \times 7 \times 26 \mathrm{~cm})\end{array}$ & $\begin{array}{l}\text { Heavy glass of the design is suitable for regular use } \\
\text { for many years. The design is sustainable against acci- } \\
\text { dental contact due to the weight (about } 15 \text { feet) and } \\
\text { the flat bottom. A clear glass allows to inspect easily } \\
\text { the contents of the chamber from all sides. A flat } \\
\text { lid provides reliable fit, it is made of milk glass with } \\
\text { edges beveled inside and outside avoiding all sharp } \\
\text { edges. The unique design of self-locking has the cor- } \\
\text { responding latches on the lid and the chamber and } \\
\text { allows the structure when closing the chamber with } \\
\text { the lid be firmly in position. Metal components of the } \\
\text { mechanism-latch lid are made of stainless steel }\end{array}$ & $156.28 \$$ \\
\hline
\end{tabular}


Table 2 continued

\begin{tabular}{|c|c|c|c|}
\hline 1 & 2 & 3 & 4 \\
\hline & $\begin{array}{l}\text { Chromatographic chamber with a } \\
\text { flat bottom, } 10 \mathrm{~cm} \text { Thinline (Latch- } \\
\text { Lid Chromatotank unit/Tank - Lid, } \\
\text { intended for plates of } 10 \times 10 \mathrm{~cm} \text { or } \\
10 \times 5 \mathrm{~cm} \text {. The size }-(12 \times 6.4 \times 11.5)\end{array}$ & $\begin{array}{l}\text { This model can place up to two plates and is suitable } \\
\text { for storing small amounts of test solvents (when select- } \\
\text { ing the optimal solvent in the process of studying the } \\
\text { unknown substances). } \\
\text { A smaller cubic size of the chamber makes it faster and } \\
\text { more evenly saturate the atmosphere with solvents and } \\
\text { use a smaller volume of the solvent. A clear glass allows to } \\
\text { inspect easily the contents of the chamber from all sides. } \\
\text { A flat lid provides reliable fit, it is made of milk glass with } \\
\text { edges beveled inside and outside avoiding all sharp edges. } \\
\text { The unique design of self-locking has the corresponding } \\
\text { latches on the lid and the chamber and allows the structure } \\
\text { when closing the chamber with the lid be firmly in position. } \\
\text { Metal components of the mechanism-latch lid are made of } \\
\text { stainless steel }\end{array}$ & $93.89 \$$ \\
\hline & & TLC or HPTLC plates & \\
\hline \multirow{20}{*}{$\begin{array}{l}\text { Sorbfil, } \\
\text { Russia, } \\
\text { Krasnodar }\end{array}$} & Sorbfil PTLC-P-A (10x10), 50 ps & \multirow{3}{*}{$\begin{array}{l}\text { Analytical, without an UV indicator. } \\
\text { Particle size: } 5-17 \mu \mathrm{m} \text {. } \\
\text { The substrate material - PET film (polyethylene } \\
\text { terephthalate) }\end{array}$} & 1480 RUB \\
\hline & Sorbfil PTLC-P-A (10x15), 50 ps & & 2200 RUB \\
\hline & Sorbfil PTLC-P-A (10x20), 50 ps & & 3350 RUB \\
\hline & Sorbfil PTLC-P-A-UV (10x10), 50 ps & \multirow{3}{*}{$\begin{array}{l}\text { Analytical, with an UV indicator }(254 \mathrm{~nm}) \text {. } \\
\text { Particle size: 5-17 } \mu \mathrm{m} \text {. } \\
\text { The substrate material - PET film }\end{array}$} & 1680 RUB \\
\hline & Sorbfil PTLC-P-A-UV (10x15), 50 ps & & 2580 RUB \\
\hline & Sorbfil PTLC-P-A-UV (10x20), 50 ps & & 3800 RUB \\
\hline & Sorbfil PTLC-P-V (10x10), 50 ps & \multirow{2}{*}{$\begin{array}{l}\text { High-performance, without an UV indicator. } \\
\text { Particle size: 8-12 } \mu \mathrm{m} \text {. } \\
\text { The substrate material - PET film }\end{array}$} & 2100 RUB \\
\hline & Sorbfil PTLC-P-V (10x15), 50 ps & & 3300 RUB \\
\hline & Sorbfil PTLC-P-V-UV $(10 \times 10), 50 \mathrm{ps}$ & \multirow{2}{*}{$\begin{array}{l}\text { High-performance, with an UV indicator. } \\
\text { PTLC-P-V-UV. } \\
\text { Particle size: } 8-12 \mu \mathrm{m} \text {. } \\
\text { The substrate material - PET film }\end{array}$} & 2300 RUB \\
\hline & Sorbfil PTLC-P-V-UV (10x15), 50 ps & & 3590 RUB \\
\hline & Sorbfil PTLC-AF-A (10×10), 50 ps & \multirow{3}{*}{$\begin{array}{l}\text { Analytical, without an UV indicator. } \\
\text { Particle size: 5-17 } \mu \mathrm{m} \text {. } \\
\text { The substrate material - aluminium foil }\end{array}$} & 1480 RUB \\
\hline & Sorbfil PTLC-AF-A (10×15), 50 ps & & 2200 RUB \\
\hline & Sorbfil PTLC-AF-A (10×20), 50 ps & & 3350 RUB \\
\hline & Sorbfil PTLC-AF-A-UV $(10 \times 10), 50$ ps & \multirow{3}{*}{$\begin{array}{l}\text { Analytical, with an UV indicator ( } 254 \mathrm{~nm} \text { ). } \\
\text { Particle size: } 5-17 \mu \mathrm{m} \text {. } \\
\text { The substrate material - aluminium foil }\end{array}$} & 1680 RUB \\
\hline & Sorbfil PTLC-AF-A-UV $(10 \times 15), 50$ ps & & 2580 RUB \\
\hline & Sorbfil, PTLC-AF-A-UV $(10 \times 20), 50$ ps & & 3800 RUB \\
\hline & Sorbfil, PTLC-AF-V (10x10), 50 ps & \multirow{2}{*}{$\begin{array}{l}\text { High-performance, without an UV indicator. } \\
\text { Particle size: } 8-12 \mu \mathrm{m} \text {. } \\
\text { The substrate material - aluminium foil }\end{array}$} & 2100 RUB \\
\hline & Sorbfil, PTLC-AF-V (10x15), 50 ps & & 3300 RUB \\
\hline & Sorbfil, PTLC-AF-V-UV $(10 \times 10), 50$ ps & \multirow{2}{*}{$\begin{array}{l}\text { High-performance, with an UV indicator. } \\
\text { Particle size: } 8-12 \mu \mathrm{m} \text {. } \\
\text { The substrate material - aluminium foil }\end{array}$} & 2300 RUB \\
\hline & Sorbfil, PTLC-AF-V-UV $(10 \times 15), 50$ ps & & 3590 RUB \\
\hline $\begin{array}{l}\text { Macherey- } \\
\text { Nagel, } \\
\text { Germany }\end{array}$ & $\begin{array}{l}\text { DC-Fertigfolien ALUGRAM } \\
\text { Sil G/UV }_{254}(20 \times 20), 25 \text { ps }\end{array}$ & $\begin{array}{l}\text { Analytical, with an UV indicator (254 nm). } \\
\text { Particle size: 5-17 } \mu \mathrm{m} \text {. } \\
\text { The substrate material - aluminium foil } \\
\end{array}$ & $1300 \mathrm{UAH}$ \\
\hline \multirow{3}{*}{$\begin{array}{l}\text { Merck, } \\
\text { Germany }\end{array}$} & Silica gel $60 \mathrm{~F}_{254}(10 \times 10), 25 \mathrm{ps}$ & $\begin{array}{l}\text { Analytical, with an UV indicator }(254 \mathrm{~nm}) \text {. } \\
\text { Particle size: } 10-12 \mu \mathrm{m} . \\
\text { The substrate material - glass }\end{array}$ & $\begin{array}{c}1868.0 \\
\text { UAH }\end{array}$ \\
\hline & Silica gel $60 \mathrm{~F}_{254}(10 \times 20), 50 \mathrm{ps}$ & $\begin{array}{l}\text { Analytical, with an UV indicator (254 nm). } \\
\text { Particle size: } 10-12 \mu \mathrm{m} \text {. } \\
\text { The substrate material - glass }\end{array}$ & $\begin{array}{l}2347.0 \\
\text { UAH }\end{array}$ \\
\hline & Silica gel $60 \mathrm{~F}_{254}(20 \times 10), 50 \mathrm{ps}$ & $\begin{array}{l}\text { High-performance, with an UV indicator }(254 \mathrm{~nm}) \text {. } \\
\text { Particle size: } 5-6 \mu \mathrm{m} \text {. } \\
\text { The substrate material - glass }\end{array}$ & $4585 \mathrm{UAH}$ \\
\hline
\end{tabular}


Table 2 continued

\begin{tabular}{|c|c|c|c|}
\hline 1 & 2 & 3 & 4 \\
\hline \multicolumn{4}{|c|}{ Device for applying } \\
\hline \multirow{5}{*}{$\begin{array}{l}\text { Sorbfil, } \\
\text { Russia }\end{array}$} & M-1, volume - $1 \mu \mathrm{l}$, without guiding (1 ps) & \multirow{5}{*}{$\begin{array}{l}\text { Calibration microsyringes are designed for } \\
\text { metered applying standard solutions and } \\
\text { dosed analytical samples on the plates. } \\
\text { The needle has a brushed straight cut }\end{array}$} & 2750 RUB \\
\hline & $\mathrm{M}-1 \mathrm{H}$, volume $-1 \mu \mathrm{l}$, with guiding (1 ps) & & 3570 RUB \\
\hline & M-10, volume - $10 \mu \mathrm{l}$, without guiding (2 ps) & & 3740 RUB \\
\hline & $\mathrm{M}-10 \mathrm{H}$, volume $-10 \mu \mathrm{l}$ with guiding (2 ps) & & 5170 RUB \\
\hline & M-50, volume $-50 \mu \mathrm{l}$, without guiding (1 ps) & & 4000 RUB \\
\hline \multirow{3}{*}{$\begin{array}{l}\text { Hamilton, } \\
\text { Switzerland }\end{array}$} & $705 \mathrm{~N}$, volume $-50 \mu \mathrm{l}$ & $\begin{array}{l}\text { A microsyringe with a fixed needle, caliber } \\
22 \mathrm{~s}(22 \mathrm{~s} / 51 / 2)\end{array}$ & $574.50 \mathrm{UAH}$ \\
\hline & $701 \mathrm{~N}$, volume $-10 \mu \mathrm{l}$ & $\begin{array}{l}\text { A microsyringe with a fixed needle, caliber } \\
26 \mathrm{~s}(26 \mathrm{~s} / 51 / 2)\end{array}$ & 4000 RUB \\
\hline & $702 \mathrm{~N}$, volume - $25 \mu \mathrm{l}$, & $\begin{array}{l}\text { A microsyringe with a fixed needle, caliber } \\
22 \mathrm{~s}(22 \mathrm{~s} / 51 / 2)\end{array}$ & $470.50 \mathrm{UAH}$ \\
\hline \multicolumn{4}{|c|}{ Devices for detecting or quenching fluorescence } \\
\hline \multirow[b]{2}{*}{$\begin{array}{l}\text { Spectroline, } \\
\text { USA }\end{array}$} & $\begin{array}{l}\text { CM-10, a cabinet with } 4 \mathrm{~W} \text { combined lamp } \\
\left(365 \mathrm{~nm} \text { with } 300 \mu \mathrm{W} / \mathrm{cm}^{2}, 254 \mathrm{~nm} \text { with }\right. \\
\left.310 \mu \mathrm{W} / \mathrm{cm}^{2}\right) . \\
\text { The size: } 22.9 \times 30.5 \times 16.5 \mathrm{~cm} \text {. } \\
\text { The weight: } 3.2 \mathrm{~kg}\end{array}$ & \multirow{2}{*}{$\begin{array}{l}\text { The multifunctional cabinet that is } \\
\text { specifically designed for use with Spectroline } \\
\text { UV lamps. It is made of aluminium coated } \\
\text { with polyurethane lacquer. } \\
\text { A protective coating against UV-radiation } \\
\text { is built in the vinyl window for looking at } \\
\text { chromatograms. The vinyl window increases } \\
\text { contrast between fluorescence area and the } \\
\text { background, reducing eye fatigue. } \\
\text { The cabinet can be ordered separately or } \\
\text { with 4-/ 6-cotton lamp, that absorbs in the } \\
\text { short-wave and long-wave regions }\end{array}$} & $450 \$$ \\
\hline & $\begin{array}{l}\text { CM-10 a cabinet with } 6 \mathrm{~W} \text { combined lamp } \\
\left(365 \mathrm{~nm} \text { with } 350 \mu \mathrm{W} / \mathrm{cm}^{2}, 254 \mathrm{~nm} \text { with }\right. \\
\left.390 \mu \mathrm{W} / \mathrm{cm}^{2}\right) . \\
\text { The size: } 22.9 \times 30.5 \times 16.5 \mathrm{~cm} \text {. } \\
\text { The weight: } 3.4 \mathrm{~kg}\end{array}$ & & $510 \$$ \\
\hline $\begin{array}{l}\text { Sorbfil, } \\
\text { Russia }\end{array}$ & $\begin{array}{l}\text { Irradiator UVL - } 254 / 365 \\
\text { The supply voltage: } 220 \mathrm{~V} \\
\text { Power consumption, VA: not more than } 30 \\
\text { The size: } 32 \times 20 \times 27 \mathrm{~cm} \text {. } \\
\text { The weight: } 5 \mathrm{~kg}\end{array}$ & $\begin{array}{l}\text { The emission source: } \\
\text { Luminescent ultraviolet lamp KLC 9/UV } \\
365 \mathrm{~nm}-1 \mathrm{ps} \\
\text { Mercury germicidal lamp DKB } 9254 \mathrm{~nm}-1 \mathrm{ps} \\
\text { The size of TLC plates is not more than - } \\
15 \times 15 \mathrm{~cm}\end{array}$ & $\begin{array}{c}13023.00 \\
\text { UAH / } \\
38800 \text { RUB }\end{array}$ \\
\hline \multicolumn{4}{|c|}{ Developing devices } \\
\hline $\begin{array}{l}\text { Sorbfil, } \\
\text { Russia }\end{array}$ & $\begin{array}{l}\text { Sprayer with a bulb, Sorbfil. } \\
\text { The sizes: height - } 170 \mathrm{~mm} \text {, diameter of the } \\
\text { sprayer - } 26-30 \mathrm{~mm} \text {. }\end{array}$ & $\begin{array}{l}\text { A sprayer is intended for applying a } \\
\text { developing reagent on chromatographic } \\
\text { plates. } \\
\text { A glass atomizer of the sprayer contains } \\
\text { system and container for solution in the } \\
\text { same body and placed on a PVC bulb }\end{array}$ & $\begin{array}{l}280.80 \text { UAH } \\
\text { / } 1200 \mathrm{RUB}\end{array}$ \\
\hline \multirow{3}{*}{ GGB, USA } & Sprayer unit, volume $-10 \mathrm{ml}$ & \multirow{3}{*}{$\begin{array}{l}\text { A screw design prevents «reverse spray- } \\
\text { ing»; made of borosilicate glass. Change- } \\
\text { able sprayer. The opportunity of choos- } \\
\text { ing a sprayer of the appropriate volume. } \\
\text { The device operates at low air pressure }\end{array}$} & $117.75 \$$ \\
\hline & Sprayer unit, volume - $50 \mathrm{ml}$ & & $117.75 \$$ \\
\hline & Sprayer unit, volume $-125 \mathrm{ml}$ & & $117.75 \$$ \\
\hline
\end{tabular}

lysing the medicinal plant raw material both analytical (TLC) and high-performance (HPTLC) plates can be used, they differ mainly in the size of the particles. During routine analysis the use of TLC plates with the particle size of 5-17 $\mu \mathrm{m}$ is enough. The presence of an UV indicator is important when choosing plates since in the pharmaceutical analysis of various classes of biologically active substances (BAS) of the medicinal plant raw material detection of many compounds occurs in UV light. Therefore, when analysing the medicinal plant raw material and drugs from it the TLC and HPTLC plates on all substrates with a UV indicator can be used. It is advisable to make the final choice based on the economic component or availability of plates.

Characteristics of the devices for applying solutions of chromatograms have revealed that when choosing microsyringes the best indicator is its volume. The volume of $10-50 \mu \mathrm{l}$ is optimal for the analysis of the medicinal plant raw material.

When comparing devices manufactured by Sorbfil (Russia) and Spectroline (USA) for detecting or quenching fluorescence it has been shown that each of the devices studied can be used to identify chromatographic zones. The manufacturer Spectroline has the quality certificate 
ISO 9001:2008 and is more affordable, therefore, it is superior to an UVS-254/365 irradiator manufactured by Sorbfil.

Comparative characteristics of the devices for spraying chromatograms (Tab. 2) have found that sprayers of GGB (USA) have a comfortable design and a suitable volume, but by cost they are much more expensive than sprayers of Sorbfil (Russia). It is advisable to make the final choice based on the economic component or availability of devices.

\section{CONCLUSIONS}

On the example of Klimased drug with the purpose of choosing the analytical equipment for quality control of combined drugs of the plant origin the major functional and performance characteristics (design qualification) of the equipment used according to pharmacopoeial requirements (SPhU and USP) and the target analytical tasks has been studied. It allows to select equipment for an enterprise.

\section{REFERENCES}

1. Волков Г.Л., Краснобрижая Е.Н., Жукова А.И. и др. // Фармачевтическая отрасль. - 2011. - №4(27). C. 36-38.

2. Державна фармакопея Украйни / Державне підприємство «Науково-експертний фармакопейний центр».1-е вид. - Х.: РІРЕГ, 2001. - 556 c.

3. Настойки, экстракты, эликсиры и их стандартизаиия / Под ред. проф. В.Л.Багировой, проф. В.А.Севериева. - С.Пб.: Спеилит, 2001. - 223 с.

4. Осмоловская И., Люлина Н. // Ремедиум. - 2005. - №5. - С. 58-62.

5. Хохлова К.О., Вишневська Л.І., Гарна С.В. та ін. // Фармаком. - 2013. - №1. - С. 38-51.

6. Хроматография. Практическое приложение метода: В 2-х ч., ч. 1 / Э.Хефтман, Т.Кастер, А.Нидервизер и др. - M.: Мup, 1986. -422 c.

7. Analytical Instrument Qualification and System Validation / Ludwig Huber // Agilent Technologies Printed in Germany, January 1, 2009. - 61 p.

8. Design Qualification Operational Qualification HPLC Equipment Case Study Publication from www. labcompliance.com Revision 1.02 May 12, 2001.

9. Unites States Pharmacopeia, Chapter <1058>, Analytical Instrument Qualification, Rockville, USA, 2008.3.

КВАЛІФІКАЦІЯ ТШХ-ОБЛАДНАННЯ, ЩО ЗАСТОСОВУЄТЬСЯ В АНАЛІЗІ КОМБІНОВАНИХ РОСЛИННИХ ПРЕПАРАТІВ

В.К.Яковенко, К.О.Хохлова

Ключові слова: система контролю якості; фрармакопейний аналіз; ТШХ-обладнання;

Клімасед

На прикладі препарату Клімасед з метою вибору аналітичного обладнання для проведення контролю якості комбінованих лікарських засобів рослинного походження досліджені головні фрункціональні і експлуатаційні характеристики (кваліфікація дизайну) обладнання, яке використовується відповідно до фрармакопейних вимог (ДФУ і USP) і поставлених аналітичних завдань, що дозволяє провести вибір обладнання для підприємства. Проведено порівняльний аналіз фрункціональних і технічних характеристик приладів для виконання аналізу комбінованих препаратів з лікарської рослинної сировини методом тонкошарової хроматографії. Експериментально доведено, що конфрігурація хроматографрічної камери не впливає на результат аналізу, за економічним показником більш доступними є камери виробництва Сорбфріл. При аналізі лікарської рослинної сировини (ЛРС) і препаратів з ЛРС можуть бути використані ТШХ- і ВЕТШХ-пластинки на всіх підложках з УФ-індикатором, остаточний вибір доцільно проводити за економічною складовою чи їх доступністю. Характеристика пристроїв для нанесення розчинів хроматограм виявила, що оптимальним показником при виборі мікрошприців є його об'єм. При порівнянні пристроїв для виявлення або гасіння фрлуоресценції виробництва Сорбфріл (Росія) i Spectroline (США) встановлено, що будь-який з досліджуваних приладів може бути використаний для виявлення хроматографрічних зон. Виробник Spectroline має сертифрікат якості ISO 9001:2008 і за ціною більш доступний, що є його перевагою над опромінювачем УФС-254/365 виробництва Сорбфріл. Серед пристроїв для обприскування хроматограм зручну конструкцію і потрібний об'єм мають пульверизатори GGB (США), але за вартістю вони є значно дорожчими за пульверизатор Сорбфіл (Росія). Остаточний вибір доцільно проводити за економічною складовою.

КВАЛИФИКАЦИЯ ТСХ-ОБОРУДОВАНИЯ, ПРИМЕНЯЕМОГО В АНАЛИЗЕ КОМБИНИРОВАННЫХ РАСТИТЕЛЬНЫХ ПРЕПАРАТОВ

В.К.Яковенко, Е.А.Хохлова

Ключевые слова: система контроля качества; анализ; ТCX-оборудование; Климасед На примере препарата Климасед с целью выбора аналитического оборудования для контроля качества комбинированных лекарственных препаратов растительного происхождения 
проведены исследования по изучению основных функциональных и эксплуатационных характеристик (квалифрикация дизайна) оборудования, которое используется в соответствии с требованиями фрармакопей (ДФУ и USP) и поставленным аналитическим заданиям, что позволяет провести выбор оборудования для предприятия. Проведен сравнительный анализ функциональных и технических характеристик приборов для выполнения анализа комбинированных препаратов из лекарственного растительного сырья методом тонкослойной хроматографии. Экспериментально доказано, что конфигурация хроматографической камеры не влияет на результат анализа, по экономическим показателям более доступными являются камеры производства Сорбфил. При анализе ЛРС и препаратов из ЛРС могут быть использованы ТСХ- и ВЭТСХ-пластинки на всех подложках с УФ-индикатором, окончательный выбор целесообразно проводить по экономической составляющей или их доступности. Характеристика приборов для нанесения растворов хроматограмм показала, что оптимальным показателем при выборе микрошприца является его объем. При сравнении приборов для обнаружения или гашения фрлуоресценции производства Сорбфил (Россия) и Spectroline (США) показано, что каждый из исследуемых приборов может быть использован для выявления хроматографических зон. Производитель Spectroline uмeem cepmuфикат качества ISO 9001:2008 и по цене более доступен, что является его преимуществом перед облучателем УФС-254/365 производства Сорбфил. Среди приборов для опрыскивания хроматограмм удобную конструкцию и подходящий объем имеют пульверизаторы GGB (США), но по стоимости они значительно дороже пульверизаторов Сорбфрил (Россия). Окончательный выбор целесообразно проводить по экономической составляющей. 